\title{
ASURANSI DALAM PANDANGAN ULAMA FIKIH KONTEMPORER
}

\author{
Abdurrauf \\ Fakultas Syariah dan Hukum UIN Jakarta \\ Jl. Ir. H. Juanda 95, Ciputat, Jakarta \\ E-mail: abdurrauf_2010@yahoo.com
}

\begin{abstract}
Abstrak: Dalam khazanah fiqh Islam klasik permasalahan asuransi dalam bentuk implementasinya yang sekarang ini memang belum dikenal, karena itu tidak didapatkan status hukumnya dalam kitab-kitab mereka. Namun demikian, kajian tentang asuransi dalam perspektif Islam kontemporer sebenarnya sudah cukup banyak dilakukan oleh para ahli hukum, baik ahli hukum Islam secara khusus maupun ahli ekonomi Islam secara umum. Mengingat asuransi ini adalah masalah yang relatif baru yang belum ada kejelasan status hukumnya pada masa pra Islam, maka perdebatan yang terjadi sekitar hukum asuransipun tidak bisa dielakkan. Sebagian ulama ada yang mengharamkannya dengan alasan adanya unsur riba, sama dengan perjudian, mengandung penipuan, ekploitasi, dan lain-lain.
\end{abstract}

Kata Kunci: Asuransi, kontemporer, qiyâs, 'illat, hukum, fikih.

\section{Pendahuluan}

Dalam perkembangan dunia modern, kebutuhan manusia tidak terbatas kepada sesuatu yang bersifat material belaka, tetapi juga meliputi jasa di berbagai bidang. Kebutuhan hidup manusia juga memerlukan pengamanan terhadap jiwa, keturunan, dan harta mereka, karena semakin maju kebudayaan rnanusia semakin kompleks pula persoalan yang mereka hadapi. Semakin berkembang ilmu pengetahuan, semakin kompleks pula resiko yang ditimbulkannya. Dalam persoalan transportasi misalnya, semakin canggih alat transportasi yang ditemukan dan digunakan manusia, semakin tinggi dan besar pula resiko yang akan dihadapi mereka. Berkendaraan dengan mobil, berlayar dengan kapal laut, dan 
terbang dengan pesawat udara, membawa kepada akibat yang bisa menghilangkan jiwa seseorang. Membangun gedung dan rumah sebagai kebutuhan hidup manusia, juga mengandung resiko kerugian benda-benda tersebut, misalnya, melalui kebakaran atau gedung dan rumah itu runtuh, baik disebabkan kelalaian manusia itu sendiri maupun oleh gejala alam (gempa) di luar kekuasaan manusia. Lebih jauh dari itu, dalam upaya menjamin kebutuhan hidup tersebut, diperlukan persiapan yang matang oleh setiap orang.

Untuk mengatasi resiko-resiko yang disebutkan di atas, di dunia modern ini dikenal suatu bentuk muamalah baru yang disebut dengan asuransi. Yaitu, suatu bentuk pertanggungan dari satu pihak kepada pihak lain berdasarkan persyaratan yang mereka sepakati.

Walaupun relatifbaru dalam khazanah fikih Islam, namunpembahasan tentang asuransi dewasa ini telah banyak dilakukan oleh para pakar hukum Islam kontemporer. Kita banyak menemukan hasil karya tentang asuransi, seperti al-Ta'mîn wa Hukmuhâ 'alâ Hudâ al-Syarî'ah al-Islâmiyah karya 'Ali al-Khafîf, al-Ta'mîn: min Wujhah Nazhr al-Syarî'ah aI-Islâmiyah karya 'Aisawi Ahmad Aisawi, Hukm al-Ta'mîn fi al-Syarî'ah al-Islâmiyah karya al-Sâdiq Muhammad al-Amin, 'Aqd al-Ta'mîn karya Musthafâ Ahmad al-Zarqâ', al-Ta'mîn al-Ijtimâ'i karya Muhammad Tal'at Isâ, 'Aqd al-Ta'mîn, karya Abdullah al-Qalqili, al-Ribâ wa al-Ta'mîn karya Murtadha Muthahhari, dan lain-lain.

Disamping karya ilmiah yang secara khusus membahas persoalan asuransi di atas, terdapat pula pembahasan tentang asuransi dalam kitabkitab fikih yang disusun oleh para ulama kontemprer, seperti Wahbah alZuhayli, dari Syiria, dalam kitab al-Fiqh al-Islâmi wa Adillatuhû, Mushtafâ Ahmad al-Zarqâ', dalam buku al-Madkhal al-Fiqh al-'Am, kadang disebut juga al-Fiqh al-Islâmi fi Tsawbihî al-Jadîd, al-Sayyid Sâbiq, dalam buku Fiqh al-Sunnah, dan lain-lain.

Namun demikian, dari sekian banyak karya tulis yang ada, penulis buku lebih banyak menitikberatkan pembahasan asuransi dilihat dari aspek hukum muamlahnya, perbedaan pendapat yang terjadi di seputar hukumnya, sejarah kemunculannya, managemen dan sistim operasionalnya, dan lain-lain. Bahkan, mayoritas penulis tentang asuransi selalu menampilkan 
perbedaan pendapat yang terjadi di kalangan ulama, walau memang hal demikian tidak bisa dielakkan, termasuk dalam artikel ini akan ditampilkan perbedaan ulama tersebut, tetapi itu dilakukan dalam rangka memudahkan untuk memetakan argumentasi dan metode penetapan hukumnya dan bukan menjadi inti tulisan.

Sedangkan dari aspek metodologis penetapan hukumnya, asuransi dalam hal ini tidak atau belum banyak disorot secara komperhensif dan mendalam. Di sinilah tulisan ini menemukan tempatnya. Maka berdasarkan alasan tersebut, penulis tertarik untuk melakukan suatu kajian tentang metode ulama fikih kontemporer dalam menetapkan hukumnya.

\section{Pengertian dan Sejarah Asuransi}

Asuransi dalam Bahasa Inggris dikenal dengan istilah insurance ${ }^{1}$, artinya asuransi dan jaminan. Dan dalam Bahasa Belanda menurut Wirjono Prodjodikoro dikenal dengan istilah assurantie, artinya asuransi, dan verzekering, artinya pertanggungan. ${ }^{2}$ Sementara Bahasa Arab menyebutnya dengan istilah ta'mîn (pengamanan), di samping juga beberapa istilah lainnya, di antaranya, takâful, tadlâmun, ta'âhud, yang semuanya dapat diartikan sebagai langkah penjaminan atau pertanggungan. ${ }^{3}$

Sedangkan secara terminologi asuransi adalah suatu ikatan yang berbentuk penggabungan kesepakatan untuk saling menolong, yang telah diatur dengan sistim yang rapi untuk sejumlah manusia yang semuanya telah siap untuk menghadapi suatu peristiwa. ${ }^{4}$ Dengan redaksi yang lain, Wirjono Prodjodikoro menyatakan bahwa asuransi adalah suatu persetujuan dimana pihak yang menjamin berjanji kepada pihak yang dijamin, untuk menerima sejumlah uang premi sebagai pengganti kerugian, yang mungkin akan diderita oleh yang dijamin, karena akibat dari suatu

${ }^{1}$ Lihat John M. Echols dan Hassan Sadilly, Kamus Inggris-Indonesia, (Jakarta: Gramedia, 1990), h. 326

${ }^{2}$ Wirjono Prodjodikoro, Hukum Asuransi di Indonesia, (Jakarta: Pembimbing, 1958), h. 1

${ }^{3}$ Lihat Muhammad Imârah, Qâmûs al-Mushthalahat al-Iqtishâdiyah fi al-Hadlârah alIslâmiyah, (Beirut: Dâr al-Syuruq, 1993), h. 124

4 'Ali al-Khafif, Al-Ta'mîn wa Hukmuhâ 'alâ Hudâ al-Syari'ah al-Islâmiyah, h. 10 
peristiwa yang belum jelas. ${ }^{5}$ Sementara Abbas Salim mengatakan asuransi adalah suatu kemauan mendapat kerugian-kerugian kecil (sedikit) yang sudah pasti sebagai pengganti (substitusi) kerugian-kerugaian besar yang belum pasti. ${ }^{6}$

Dalam Ensiklopedi Hukum Islam, asuransi didefinisikan dengan transaksi perjanjian antara dua pihak; pihak yang satu berkewajiban membayar iuran dan pihak yang lain berkewajiban memberikan jaminan sepenuhnya kepada pembayar iuran jika terjadi sesuatu yang menimpa pihak pertama sesuai dengan perjanjian yang dibuat. ${ }^{7}$ Kemudian, terakhir untuk definisi, penulis juga menukil rumusan definitif yang dituangkan pada Pasal 1 Undang-Undang No. 2 Tahun 1992 tentang Usaha Perasuransian sebagai berikut:

"Asuransi atau pertanggungan adalah perjanjian antara dua pihak atau lebih, dengan mana pihak penanggung mengikatkan diri kepada tertanggung dengan menerima premi asuransi, untuk memberikan penggantian kepada tertanggung karena kerugian, kerusakan atau kehilangan keuntungan yang diharapkan, atau tanggung jawab hukum kepada pihak ketiga yang mungkin akan diderita tertanggung, yang timbul dari suatu peristiwa yang tidak pasti, atau untuk memberikan suatu pembayaran yang didasarkan atas meninggal atau hidupnya seseorang yang dipertanggungkan". ${ }^{8}$

Berdasarkan definisi tersebut dapat dikatakan bahwa asuransi merupakan salah satu bentuk pertanggungan terhadap musibah yang diperkirakan sewaktu-waktu akan terjadi. Karena itu, muncullah berbagai macam jenis asuransi atau pertanggungan, seperti asuransi jiwa, asuransi kecelakaan, asuransi kebakaran, asuransi pendidikan, bahkan asuransi yang berkaitan dengan pertanian dan pelaksanaan ibadah haji. Definisidefinisi di atas sekalipun secara redaksional ada sedikit perbedaan, namun terdapat benang merah yang menegaskan bahwa secara sub-

${ }^{5}$ Wirjono Prodjodikoro, Hukum Asuransi di Indonesia, h. 1

${ }^{6}$ Abbas Salim, Dasar-dasar Asuransi (Principiles of Insurance), cet. ke-1, (Jakarta: PT. Rajagrapindo Persada, 1995), h.1

${ }^{7}$ Abdul Aziz Dahlan, dkk (editor), Ensiklopedi Hukum Islam, (Jakarta: Ictiar Baru van Hoeve, 1996), h. 138.

${ }^{8}$ Warkum Sumitro, Asas-asas Perbankan Islam dan Lembaga-lembaga Terkait, cet. ke-4 (Jakarta: Rajawali Press, 2004), h. 186 
stansial asuransi bertujuan untuk saling membantu dan menolong sesama. Mushtafâ Ahmad al-Zarqâ' menyatakan bahwa akad asuransi itu merupakan suatu sistim tadlâmun dan ta'âwun yang bertujuan untuk menutupi kerugian yang disebabkan oleh musibah. ${ }^{9}$

Jika ditelusuri dari sejarah kemunculannya, Afzalur Rahman mencatat konsep asuransi sangat berkaitan erat dengan kehidupan berkelompok. Dalam masyarakat primitif, orang biasanya hidup bersama dalam suatu keluarga besar atau suku dimana kebutuhan-kebutuhannya terpenuhi dan terlindungi melalui kerjasama dan saling membantu. Oleh karena itu, mereka merasa tidak memerlukan suatu asuransi karena resiko sepenuhnya dilindungi oleh masyarakat. Dan pada waktu keluarga atau suku berubah menjadi kehidupan yang berpindah-pindah, secara individu keluarga tersebut mengahadapi berbagai macam bahaya tanpa adanya perlindungan dari keluarga maupun sukunya. Karena keadaan yang demikian itu, seorang individu secara mandiri terlepas sepenuhnya dari perlindungan keluarga maupun sukunya, sehingga ia mencari bentukbentuk perlindungan lain. ${ }^{10}$

Jadi menurut Afzalur Rahman, asuransi bermula dari manusia yang membutuhkan perlindungan terhadap kemungkinan resiko yang dihadapi atas dirinya, harta, maupun kepentingannya. Hanya saja, sejak kapan, bagaimana dan oleh siapa asuransi itu dimulai masih merupakan teka-teki yang perlu dicari jawabannya. ${ }^{11}$

Namun menurut Muhammad Sayyid al-Dasûqi, peraturan yang mengatur tentang asuransi, pertama kali muncul di Spanyol dan Portugal pada abad ke-15 M. Peraturan perasuransian ini dikenal dengan sebutan Peraturan Bercelona yang disahkan pada tahun 1436, 1458, 1461, dan 1484. Pada tahun-tahun itu terjadi perkembangan peraturan perasuransian, kemudian pada tahun 1601, pemerintah Inggris mengeluarkan undangundang yang mengatur perasuransian, khususnya yang berkaitan dengan h. 403 .

${ }^{9}$ Mushtafâ Ahmad al-Zarqâ', 'Aqd al-Ta'mîn wa Mawqif al-Syarî'ah al-Islâmiyah Minhu,

${ }^{10}$ Afzalur Rahman, Doktrin Ekonomi Islam, (terj. Soeroyo dan Nastangin,), Vol. ke-4, (Yogyakarta: PT. Dana Bakti Wakaf, 1996), h. 29

${ }^{11}$ Afzalur Rahman, Doktrin Ekonomi Islam, h. 30 
asuransi kelautan (pelayaran). ${ }^{12}$

Dengan demikian, asuransi yang pertama kali muncul di Eropa adalah yang berkaitan dengan keselamatan pelayaran dan dilanjutkan dengan asuransi jiwa sebagai konsekuensi pertanggungan terhadap keselamatan pelayaran. Pada perkembangan selanjutnya, asuransi berkembang pula terhadap pertanggungan kecelakaan di darat, seperti kebakaran, asuransi bangunan, asuransi mobil, pendidikan dan seterusnya yang bertujuan untuk memberikan pertanggungan dalam berbagai sektor kehidupan.

Muhammad Muslehuddin menambahkan, bila tujuan utama asuransi itu adalah tindakan preventif dan antisipatif, maka sesungguhnya praktik asuransi sudah dikenal sejak zaman sebelum Masehi dimana manusia pada masa itu telah melakukan suatu antisipasi untuk menyelamatkan jiwanya dari berbagai ancaman, antara lain dari kekurangan bahan makan. Salah satu cerita yang dikemukakan mengenai tindakan antisipasi dari kekurangan bahan makanan itu adalah cerita pada zaman Mesir Kuno semasa Raja Fir'aun berkuasa. ${ }^{13}$

Berdasarkan penjelasan di atas, asuransi dalam kontek tersebut dapat dikatakan sejalan dengan tujuan-tujuan umum syariah (maqâshid alSyarî'ah $)^{14}$, karena menurut rumusannya, asuransi adalah sebuah gabungan kesepakatan untuk saling tolong-menolong, yang diatur dalam suatu aturan antara sejumlah besar manusia, dengan tujuan untuk menghilangkan atau meringankan kerugian akibat peristiwa yang menimpa. ${ }^{15}$

\section{Asuransi dalam Khazanah Fikih Kontemporer}

Jika ditilik ke dalam khazanah fiqih Islam kontemporer, akan kita jumpai berbagai silang pendapat di kalangan para pemikir Islam dalam menentu-

${ }^{12}$ Muhammad Sayyid al-Dasûqi, Al-Ta'mîn wa Mawqif al-Syarî̀ah al-Islâmiyah Minhu, (Kairo: Majlis al-A'lâ li al-Syu'ûn al-Islâmiyah, 1968), h. 13.

${ }^{13}$ Muhammad Muslehuddin, Insurance and Islamic Law, (terj. Burhan Wirasubrata, Menggugat Asuransi Modern: Mengajukan suatu alternative baru dalam perspektif Islam, (Jakarta: Lentera, 1999), h. 7-12.

${ }^{14}$ Lihat, al-Syâthibi, Al-Muwâfaqât fi Ushûl al-Syarî̀ah, vol. 1, cet.ke-4, (Beirut: Dâr alMa'rifah, 1420 H- 1999 M), h. 325-326.

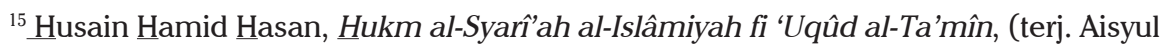
Muzakki Ishak), (Jakarta: Pustaka Firdaus, 1996), h. 4. 
kan hukum asuransi ini. Ada yang mengatakan bahwa asuransi itu hukumnya haram secara mutlak dengan dasar bahwa di dalam akad asuransi terdapat unsur riba, dan riba jelas-jelas dilarang oleh agama. ${ }^{16}$ Ada pula yang berpendapat bahwa asuransi termasuk perkara syubhat, dengan alasan tidak ada yang secara tegas menunjukkan hukumnya, halal atau haram. ${ }^{17}$ Selain itu, ada pula ulama yang membolehkan sebagaian bentuk asuransi dan mengharamkan sebagian lainnya, karena menurut mereka asuransi termasuk ke dalam kategori muamalah yang mengandung manfaat. ${ }^{18}$

Dewan Yurisprudensi Islam Liga Dunia Muslim, Mekkah, Saudi Arabia, menganggap bahwa semua transaksi asuransi modern termasuk asuransi jiwa dan niaga adalah bertentangan dengan ajaran Islam, akan tetapi Dewan menyetujui adanya "Asuransi Koperatif." 19

Syaikh Ahmad Musthafâ al-Zarqâ' mengatakan bahwa hukum asuransi adalah boleh (mubâh), karena hukum asal dari segala sesuatu itu adalah halal/boleh (al-ibâhah), di samping juga syarak tidak hanya membatasi pada akad klasik yang sudah diketahui saja, dan juga tidak melarang adanya bentuk akad baru yang muncul kemudian sesuai kebutuhan zaman selama tidak bertentangan dengan aturan akad syariah dan syaratsyaratnya secara umum, di samping juga karena adanya kesesuaian antara akad asuransi dengan akad-akad mumalah yang berkembang pada masa pra Islam yang diakui kebolehannya oleh syariah, seperti akad muwâlah, ${ }^{20}$ nizhâm 'aqilah, ${ }^{21}$ dan lain-lain.

${ }^{16}$ Al-Sayyid Sâbiq, Fiqh al-Sunnah, Vol.ke-3, (Beirut: Dâr al-Kutub al-Ilmiyah, 1998), h. 300-304.

${ }^{17}$ Yûsuf al-Qaradlâwi, al-Halâl wa al-Harâm fi al-Islâm, (Mesir: Dâr al-Fikr al-'Arabi, 1984), h. 56

${ }^{18}$ Abd al-Rahmân Isâ, al-Mu'âmalat al-Haditsah wa Ahkamuha, (Mesir: al-Mukhaimir, t.t.), h. 8 .

${ }^{19}$ Muhammad Abdul Manan, Teori dan Praktik Ekonomi Islam, (editor, H.M. Sonhadji, dkk), (Yogyakarta: PT. Dana Bakti Prima Yasa, 1997), h. 305

${ }^{20}$ Akad muwalah adalah adalah kesepakatan yang terjadi antara seorang yang masuk agama Islam dari kalangan non Arab dengan seorang arab muslim agar: ia (arab muslim) membayar diyat jika muslim baru dari kalangan non arab tadi melakukan suatu jinayah, sementara muslim muallaf tadi menyepakati juga untuk menjadi ahli waris arab muslim itu jika ia tidak mempunyai ahli waris lain. (Lihat Isa Abduh, al-Ta'mîn baina al-Hilli wa alTahrim, (al-Qahirah: Dar al-I'tisham, t.t.), h. 140)

${ }^{21}$ Nidham 'aqilah adalah hubungan nasab menurut hirarki ahli waris. Menurut konsep 
Sependapat dengan al-Zarqâ', 'Abd al-Wahhâb al-Khallâf mengatakan, asuransi hukumnya boleh (jâiz), karena termasuk akad mudlârabah. Dan mudlârabah adalah akad berserikat di dalam keuntungan, dimana satu pihak bermodalkan harta, dan satu pihak lagi bermodalkan tenaga dan kerja. Dan dalam praktik ta'mîn sendiri kata beliau, modal bersumber dari para peserta ta'mîn yang membayar premi dan sementara tenaga dan managemen ada pada pihak perusahaan yang mengembangkan modal tersebut, dan keuntungan dibagi antara perusahaan dan peserta sesuai akad. ${ }^{22}$

Berbeda dengan dua pakar hukum Islam di atas, Yûsûf al-Qaradlâwi dalam "Al-ㅌalâl wa al-Haram fi al-Islâm" mengatakan bahwa diharamkannya asuransi konvensional karena (1) semua anggota asuransi tidak membayar uangnya itu dengan maksud tabarru', bahkan nilai ini sedikitpun tidak terlintas, (2) lembaga atau perusahaan asuransi pada umumnya memutar/ menginvestasikan kembali dana-dana tersebut dengan jalan riba. ${ }^{23}$

Muhammad Abu Zahrah membolehkan asuransi yang bersifat sosial (ta'mîn ta'âwuni), dan mengharamkan yang bersifat komersial. Alasan membolehkan yang bersifat sosial kurang lebih sama dengan alasan mereka yang membolehkan asuransi secara umum, demikian juga alasan mengharamkan asuransi yang bersifat komersial sama dengan alasan mereka yang mengharamkan asuransi. ${ }^{24}$

Dari penjelasan di atas perbedaan pendapat tentang asuransi berkisar pada empat status hukum; boleh, haram, syubhat, hukum yang membedakan antara asuransi sosial dan asuransi komersial. Dan secara garis besar penulis di sini mempetakannya menjadi dua kelompok perbedaan, karena alasan mereka yang mengatakan asuransi komersial itu tidak boleh dan syubhat, sama dengan alasan mereka yang mengharamkan asuransi.

\footnotetext{
'aqilah: apabila seseorang dari keluarga melakukan pembunuhan secara bersalah, maka yang menjamin dendanya adalah ahli warisnya. (Lihat Isa Abduh, al-Ta'mîn baina al-Hilli wa al-Tahrim, (al-Qahirah: Dar al-I'tisham, t.t.), h. 138)

${ }^{22}$ Isâ Abduh, Al-Ta'mîn Bayna al-Hill wa al-Tahrîm, (Kairo: Dâr al-I'tishâm, t.t.), h. 154.

${ }^{23}$ Isâ Abduh, Al-Ta'mîn Bayna al-Hill wa al-Tahrîm, h. 154.

${ }^{24}$ Masjfuk Zuhdi, Masâil Fiqhiyah, (Jakarta: Haji Masagung, 1994); M. Ali Hasan, Masâil Fiqhiyah, (Jakarta: Raja Grafindo Persada, 2003), h. 95.
} 
Dengan demikan, asuransi sebagai bentuk muamalah baru dalam dunia ekonomi modern merupakan masalah ijtihâdiyyah dan khilâfiyyah dalam khazanah fikih Islam kontemporer, yaitu masalah yang status hukumnya didapat dari hasil ijtihad dan oleh sebab itu belum ada kesepakatan tentang status hukumnya. Perbedaan hasil ijtihad ini muncul karena banyak faktor, di antaranya perbedaan cara melihat kasus, perbedaan latar belakang pendidikan, dll.

\section{Perdebatan tentang Hukum Asuransi}

Pada prinsipnya berbagai bentuk muamalah modern dapat diterima selama hal tersebut tidak bertentangan dengan prinsip-prinsip dasar Islam. Islam tidak menafikan bahwa kreasi manusia terhadap berbagai bentuk muamalah akan senantiasa berkembang sesuai dengan perkembangan peradaban dan ilmu pengetahuan yang mereka capai. Menyadari hal tersebut, para ulama menyusun sebuah kaidah fikih yang sangat fleksibel dan elastis sebagai acuan dalam menyoroti suatu masalah baru, yaitu "alashl fi al-mu'âmalah al-ibâhah hattâ yadullu al-dalîl 'alâ tahrîmih" ${ }^{25}$ artinya, "prinsip dasar dalam persoalan mu'amalah adalah boleh (dilakukan) sampai ada dalil yang menunjukkan keharamannya".

Di antara bentuk muamalah yang kemudian direkayasa dan dikembangkan oleh para ilmuan modern adalah asuransi.

Dilihat dari segi tujuan dan sasaran yang akan dicapai sebagaimana yang telah dikemukakan pada pembahasan sebelumnya, bahwa asuransi mempunyai nilai positif bagi kehidupan manusia karena prinsip ta' âwun dan takâful ijtimâ’i merupakan termasuk bagian dari ajaran Islam yang amat fundamental sebagaimana termaktub dalam Q.s. al-Mâ'idah [5]: 2, "dan tolong-menolonglah kamu dalam (mengerjakan) kebajikan dan taqwa.

Namun pada tataran operasional, konsep ideal dengan tujuan dan sasaran yang baik di suatu perusahaan asuransi itu, terkadang terkesan adanya ketidaksesuaian antara konsep atau teori idealnya dengan praktik

${ }^{25}$ Jalâl al-Dîn Abd al-Rahmân al-Suyûthi, al-Asybâh wa al-Nazhâir, (Singapore: Sulaiman Mar'ie, t.t.), h. 123. 
yang terjadi di lapangan. Di sinilah kemudian muncul persoalan dan perbedaan pendapat para ulama fikih kontemporer tentang kedudukan hukum asuransi tersebut.

Terkait dengan persoalan perbedaan pendapat ini, penulis akan memetakan perbedaan pendapat tersebut, berikut argumentasi-argumentasi masing-masing kelompok kepada dua kutub, ${ }^{26}$ yakni pendapat yang mengharamkan asuransi dan yang membolehkan asuransi. Kelompok pertama diwakili oleh Wahbah al-Zuhayli, ${ }^{27}$ al-Sayyid Sâbiq, ${ }^{28}$ Jalâl Mushtafâ al-Shayyâd, ${ }^{29}$ Husain Hâmid Hasan, ${ }^{30}$ Yusuf al-Qaradlâwi, ${ }^{31}$ Muhammad Bakhit al-Muthi'i, ${ }^{32}$ Abd al-Rahmân Qarâ'ah, ${ }^{33}$ dan Shâdiq Muhammad Amin. ${ }^{34}$ Alasan-alasan yang dikemukakan oleh kelompok ini adalah (1) perusahaan asuransi yang ada selama ini dalam mengivestasikan dan mereasuransikan dana atau premi para pemegang polis dengan cara praktik riba, (2) asuransi pada hakikatnya sama atau serupa dengan judi. Membantah alasan yang membolehkan, mereka mengatakan keridhaan kedua belah pihak tidak menjadi ukuran karena antara pemakan riba dan wakilnya sama-sama ridha, (3) mengandung unsur ketidakjelasan, (4) mengandung unsur riba/rente, (5) mengandung unsur eksploitasi, karena pemegang polis kalau tidak bisa melanjutkan pembayaran preminya, bisa

${ }^{26}$ Masjfuk Zuhdi membagi perbedaan ulama dalam kasus asuransi menjadi 4 (empat) pendapat, namun dalam makalah ini penulis mempetakannya menjadi dua kelompok karena alasan kelompok yang mengatakan asuransi itu syubhat hampir sama dengan yang mengharamkannya, demikian pula yang mengatakan tidak haram secara mutlak alasannya hampir sama dengan yang mengatakan haram. (Lihat, Masjfuk Zuhdi, Masail Fiqhiyah, (Jakarta: Haji Masagung, 1994).

${ }^{27}$ Lihat dalam kitabnya, al-Fiqh al-Islâmiy wa Adillatuhu, Vol. ke-IV, (Beirut: Dar alFikr, 1982), H. 441.

${ }^{28}$ Al-Sayyid Sâbiq, Fiqh al-Sunnah, (Beirut: Dar al-Kutub al-Ilmiyah, 1983)

${ }^{29}$ Jalâl Mushtafâ al-Shayyâd "al-Ta'mîn wa Ba'dlus Syubhât", (makalah disampaikan pada seminar pertama tentang Ekonomi Islam di Mekah, Pebruari 1976).

${ }^{30}$ Lihat dalam karyanya, Hukm al-Syari'ah al-Islâmiyah fi 'Uqud al-Ta'mîn, (al-Qâhirah: Dâr al-Nahdlah al-'Arabiyah, 1976).

${ }^{31}$ Lihat dalam karyanya al-Halâl wa al-Harâm fi al-Islam

${ }^{32}$ Lihat dalam buku Isâ Abduh, Al-Ta'mîn Bayna al-Hill wa al-Tahrîm, (al-Qâhirah: Dâr al-I'tisham, t.t.), h. 176

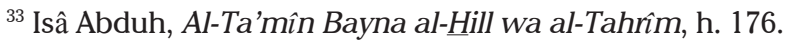

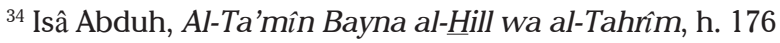


hilang atau dikurangi uang premi yang telah dibayarkan, (6) di samping akad ta'mîn mengandung unsur riba, ia juga mengandung unsur murâhanah, (7) bahwa akad ta'mîn termasuk akad spekulatif dan mengandung gharar, dan (8) hidup dan mati manusia dijadikan obyek bisnis, yang berarti mendahului takdir Tuhan Yang Mahakuasa.

Kelompok kedua diwakili oleh "Abd al-Rahmân Isâ, ${ }^{35}$ Muhammad al-Bâhi, ${ }^{36}$ Abd al-Munshif Mahmûd, ${ }^{37} \mathrm{Abd}$ al-Wahhâb al-Khallâf, ${ }^{38}$ 'Ali alKhafîf, ${ }^{39}$ Taufiq 'Ali Wahbah, ${ }^{40}$ Muhammad Yûsûf Mûsa, ${ }^{41}$ dan lain-lain. Kebolehan asuransi menurut kelompok ini mengacu pada sejumlah alasan, yakni (1) praktik perusahaan asuransi saat ini tidak lain bertujuan untuk memberikan khidmah (pelayanan) kepada masyarakat, berupa jaminan atas adanya resiko dan musibah yang menimpa, (2) akad ta'mîn menyerupai akad muwâlah karena pada kedua belah pihak adanya kewajiban-kewajiban yang harus dilaksanakan, (3) akad ta'mîn menyerupai nizhâm 'awâqil dalam Islam, (4) akad ta'mîn termasuk akad mudlârabah (5) akad ta'mîn bukanlah akad jual-beli, akan tetapi termasuk akad tadlâmun/takâfuli antara para peserta asuransi dalam menghadapi musibah dan meringankan dampaknya, (6) akad ta'mîn termasuk akad mu'âwadlah (pertukaran).

Di samping alasan-alasan di atas, faktor manfaat juga menjadi alasan bagi mereka membolehkan asuransi. Di antara manfaat asuransi menurut mereka adalah (1) sebagai sarana atau langkah kehati-hatian dan tindakan preventif, (2) adanya rasa ketenangan dan keamanan, (3) dapat membantu

${ }^{35}$ Dalam Bukunya, al-Mu'âmalat al-Haditsah wa Ahkâmuha, (Mesir: Mukhaimir, t.t.), h. 83-89.

${ }^{36}$ Lihat Muhammad al-Bâhi, Nidhâm alTa'mîn fi Hâdi Ahkâm al-Islâm wa Darurat alMujtama' al-Mu'âshir, (al-Qâhirah: Maktabah Wahbah, 1965), h. 12.

${ }^{37}$ Abdul Munshif Mahmûd, al-Ta'mîn al-Ta'âwuni wa al-Ijtimâ'i fi al-Mizân, dalam Majalah Minbar al-Islam, No. ke-1, Muharram Tahun 1388 H.

${ }^{38}$ Abdul al-Wahhâb al-Khallâf, al-Ta'mîn, dalam majalah, Liwa' al-Islam, No.ke-11, Tahun VIII.

${ }^{39}$ Syaikh Ali al-Khafif, "al-Ta'mîn wa Hukmuhu 'alâ Hadyi al-Syari'ah wa Ushuluhâ al'Ammah", makalah disampaikan pada seminar pertama tentang Ekonomi Islam, di Mekah, Pebruari 1976.

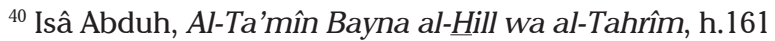

${ }^{41}$ Isâ Abduh, Al-Ta'mîn Bayna al-Hill wa al-Tahrîm, h. 159 
mengurangi beban ketika terjadi musibah, yang belum tentu sanggup ia tanggung sendiri, (4) sebagai sarana untuk kemajuan ekonomi dan pembangunan, (5) termasuk akad mudlârabah, dimana peserta asuran sebagai penanam modal dan pihak asuransi sebagai pengemban usaha, dan keuntungan di antara mereka dibagi sesuai akad, (6) mengandung manfaat dan kepentingan umum (mashlahah 'âmah), sebab premi-premi yang terkumpul bisa diinvestasikan untuk proyek-prpyek yang produktif dan untuk pembangunan.

\section{Metode Penetapan Hukum Asuransi}

Bila kita cermati pandangan dari kedua kelompok di atas, maka dapat ditemukan kesamaan metode dalam pemaparan argumentasi, di mana kedua pihak menggunakan metode qiyâs ${ }^{42}$ (analogi) dalam menetapkan hukum asuransi. Pada kelompok yang mengharamkan asuransi, metode qiyâs ini dapat dilihat, misalnya, asuransi dianalogikan dengan riba, la'ab al-maysir (permainan judi), bay'i' garar (jual beli dengan unsur penipuan), dan lain-lain. Dan pada kelompok yang membolehkan asuransi, metode qiyâs ini misalnya, tampak ketika mereka menganalogikan asuransi dengan akad mudlârabah ${ }^{43}$, muwâlah ${ }^{44}$ dan nizhâm al- 'awâqil ${ }^{45}$ dalam Islam.

Untuk dapat memahami konsep qiyâs dalam penetapan hukum, ada baiknya ditelusuri terlebih dahulu cara kerja qiyâs itu sendiri. Karena dengan demikian kita dapat memahami pokok masalah yang se-

${ }^{42}$ Secara definitif, Abd al-Wahhâb al-Khallâf merumuskan qiyâs sebagai berikut: menyamakan suatu kasus yang tidak terdapat hukumnya dalam nash (Alquran dan alSunnah) dengan kasus yang hukumnya terdapat dalam nash, karena adanya persamaan 'illat dalam kedua kasus hukum itu. (Lihat Abd al-Wahhâb al-Khallâf, Mashâdir al-Tasyri' al-Islâmi fi ma lâ nashsha fih, (Kuwait: Dâr al-Qalam, 1972), h. 19

${ }^{43}$ Akad mudlârabah adalah suatu sistem perniagaan di mana si pemilik modal (shâhib al-mâl) menyetorkan modalnya kepada pengusaha, yang selanjutnya disebut mudlârib, untuk diniagakan dengan keuntungan akan dibagi bersama sesuai dengan kesepakatan dari kedua belah pihak, sedangkan kerugian, jika ada, akan ditanggung oleh si pemilik modal. (lihat Institut Bankir Indonesia, Konsep, Produk dan Implementasi Operasional Bank Syarîah, (Jakarta: Djambatan, 2001), h. 164.

${ }^{44}$ Pengertiannya lihat halaman 9

${ }^{45}$ Pengertiannya lihat halaman 10 
sungguhnya. Disamping itu, qiyâs sebagai salah satu metode penetapan hukum, mempunyai syarat dan rukun yang menjadi standar kerjanya. Rukun qiyâs yang dimaksud adalah, ${ }^{46}$ pertama: ashl (pokok), kadang disebut pula dengan maqîs 'alaih. Yang dimaksud dengan ashl adalah suatu kasus yang sudah ada nash-nya yang dijadikan dasar analogi. Kedua, far' (cabang), kadang disebut maqîs (yang dianalogikan) atau musyabbah (yang diserupakan). Yang dimaksud dengan far' adalah kasus baru yang belum ada nash-nya dan yang akan dianalogikan dengan ashl. Ketiga, hukum ashl, yaitu hukum syarak terhadap ashl. Hukum syarak di sini bisa halal, haram, dan seterusnya. Keempat, 'illat atau motif yang menjadi alasan untuk menetapkan suatu hukum.

Menurut Fathurrahman Djamil, dari keempat unsur (rukun) di atas, unsur yang disebut terakhir, 'illat, adalah sangat penting dan menentukan. Karena ada atau tidak adanya hukum dalam kasus baru sangat tergantung pada ada atau tidak adanya 'illat pada kasus tersebut. ${ }^{47} \mathrm{Hal}$ ini berdasarkan kaidah "al-hukm yadûru ma'a al-'illat wujûdan wa 'adaman" hukum itu tergantung pada ada atau tidak adanya 'illat. Sedangkan yang dimaksud dengan 'illat menurut Wahbah al-Zuhayli adalah sesuatu sifat yang jelas dan ada tolak ukurnya, menginformasikan tentang ada atau tidak adanya hukum yang akan ditetapkan berdasarkan sifat dimaksud. ${ }^{48}$

Pengertian 'illat yang dikemukakan di atas sekaligus menjelaskan fungsi 'illat itu sendiri, yaitu sebagai alasan untuk menetapkan hukum suatu kasus, dimana keberadaannya merupakan penentu adanya suatu hukum. Kasus lama yang banyak dicontohkan dalam kitab-kitab fikih adalah kasus seorang sahabat Nabi Saw. yang sengaja membatalkan puasa Ramadhan dengan jima' di siang hari. ${ }^{49}$ Kemudian para ulama menarik hukum dari

${ }^{46}$ Rachmat Syafe'i, Ilmu Ushul Fiqh untuk IAIN, STAIN, PTAIS, (Bandung: Pustaka Setia, 1999), h. 87

${ }^{47}$ Fathurrahman Djamil, Filsafat Hukum Islam, cet.ke-III, (Pamulang: Logos Wacana Ilmu, 1999), h. 135-136

${ }^{48}$ Wahbah al-Zuhayli, al-Wasîth fî Ushûl Fiqh, (Dimasyqi: al-Mathba'at al-'Ilmiyyat, 1969), h. 415.

${ }^{49}$ Lengkap kasusnya dijelaskan dalam salah satu hadits Nabi s.a.w. berikut: "Seorang lelaki datang kepada Rasulullah s.a.w. dan berkata: Celaka aku ya Rasulullah. Rasulullah bertanya: celaka kenapa ?. Ia menjawab: aku telah bersetubuh dengan isteriku (jima') 
kasus tersebut. Sebahagian mereka, seperti Abû Hanifah, Imâm Mâlik, Imâm Tsawri, dan lain-lain mengatakan bahwa orang yang melakukan jima' di siang hari Ramadhan wajib baginya mengganti puasa Ramadhannya di hari lain dan kaffârat. 'Illat (alasan) mereka menetapkan hukum wajib dan kaffârat adalah karena perbuatan tersebut dianggap merusak kehormatan bulan suci Ramadhan.

Sedangkan kasus baru (far') yang dianalogikan dengan kasus lama (ashl), yang belum ada nash atau ketetapan hukumnya adalah kasus makan dan minum dengan sengaja di bulan Ramadhan. Mereka menganggap orang yang makan dan atau minum di siang hari Ramadhan dengan sengaja itu sama dengan orang yang melakukan jima' di siang hari Ramadhan. Hukumnya sama, wajib qadla' dan kaffârat, dan berdasarkan 'illat yang sama pula menurut mereka.

Dalam kaitannya dengan kasus asuransi, di antara kasus lama yang dijadikan analogi adalah kasus praktik riba, bay' al-garar (jual-beli yang mengandung penipuan dan ketidakjelasan), maysir (perjudian), mudlârabah, nizhâm 'awâqil, dan muwâlah.

Namun mengingat keterbatasan yang ada, penulis hanya mengetengahkan 3 (tiga) contoh kasus yang dapat dianalogikan dengan asuransi, yaitu analogi asuransi dengan praktik riba, analogi asuransi dengan bay' al-garar, dan analogi asuransi dengan la'b al-maisir.

Agar lebih mudah memahami cara kerja qiyas dalam kasus asuransi ini, penulis menyajikannya dalam bentuk skema atau tabel berikut:

di siang hari Ramadhan. Rasul s.a.w. berkata: apakah kamu mempunyai sesuatu untuk memerdekakan seorang budak ?. Ia menjawab: tidak punya. Nabi s.a.w. bertanya lagi: Mampukah kamu berpuasa dua bulan berturut-turut ?. Ia menjawab: tidak mampu. Nabi s.a.w. berkata lagi: punyakah kamu sesuatu untuk disedekahkan kepada orang miskin ?. Ia menjawab: tidak punya. Kemudian ia duduk, lalu Nabi s.a.w. memberikannya karung yang di dalamnya terdapat kurma. Nabi s.a.w. berkata: bersedekahlah kamu dengan ini. Ia berkata: apakah aku harus menyedekahkan kepada orang yang lebih miskin dariku, padahal tidak satu keluargapun di kampungku yang lebih membutuhkan dari keluargaku. Nabi s.a.w. tertawa dan berkata: pergilah dan bersedekahlah kepada keluargamu dengan makanan tersebut. (HR. Bukhari dan Muslim). 


\section{Contoh 1}

Kasus yang ada nash 1: (Yang dianalogikan dengannya)

\begin{tabular}{|c|c|c|}
\hline PRAKTIK RIBA & HUKUM & ILLAT \\
\hline $\begin{array}{l}\text { Riba adalah pengambilan tamba- } \\
\text { han dari harta pokok atau modal } \\
\text { secara bathil' }{ }^{1} \text { Atau dengan kata lain, } \\
\text { menetapkan tambahan tertentu atas } \\
\text { pokok harta pada awal akad } \\
\text { Misal: } \\
\text { Tuan A mau meminjamkan duit } \\
\text { ke Tuan B sebesar Rp. } 1.000 .000,- \\
\text { dalam tempo } 3 \text { bulan untuk keper- } \\
\text { luan keluarga, dengan syarat apabila } \\
\text { tuan B tidak bisa melunasinya pada } \\
\text { waktu yang telah disepakati maka } \\
\text { ia wajib membayar uang tambahan } \\
\text { sebesar } 100.000,- \text {. }\end{array}$ & $\begin{array}{l}\text { Haram ber- } \\
\text { dasarkan } \\
\text { al-Qur'an dan } \\
\text { al-Hadits }\end{array}$ & $\begin{array}{ll}\text { 1. } & \text { adanya tambahan pada } \\
\text { pokok harta yang ditetap- } \\
\text { kan di awal berdasarkan } \\
\text { tenggang waktu, yaitu dari } \\
\text { Rp. } 1.000 .000,- \text { menjadi Rp. } \\
\text { 1.100.000,-. } \\
\text { di anggap riba karena } \\
\text { adanya unsur kedzaliman, } \\
\text { dimana Tuan B sudah jatuh } \\
\text { ketimpan tangga lagi. ini } \\
\text { dalam perspektif al-Qur'an } \\
\text { tindakan kedzaliman (QS. } \\
\text { al-Baqarah, 2: 278-280). }\end{array}$ \\
\hline
\end{tabular}

\section{Kasus baru: (Yang dianalogikan dengan kasus riba)}

\begin{tabular}{|c|c|c|}
\hline ASURANSI & HUKUM & ILLAT \\
\hline $\begin{array}{l}\text { Asuransi adalah transaksi perjanjian } \\
\text { antara dua pihak; pihak yang satu berke- } \\
\text { wajiban membayar iuran dan pihak yang } \\
\text { lain berkewajiban memberikan jaminan } \\
\text { sepenuhnya kepada pembayar iuran } \\
\text { jika terjadi sesuatu yang menimpa pihak } \\
\text { pertama sesuai dengan perjanjian yang } \\
\text { dibuat"2. } \\
\text { Contoh ilustrasi3: } \\
\text { Takaful Dana Siswa: } \\
\text { Bapak Ali, usia } 30 \text { tahun, mengikuti pro- } \\
\text { gram TAKAFUL DANA SISWA dengan } \\
\text { membayar premi Rp. } 1.000 .000,- \text { tiap } \\
\text { tahun untuk jangka waktu } 17 \text { tahun. } \\
\text { Bila bapak Ali panjang umur hingga per- } \\
\text { janjian berakhir, akan menerima dana } \\
\text { pendidikan untuk anaknya (dengan } \\
\text { asumsi tingkat investasi } 12 \% \text { ), sebagai } \\
\text { berikut: }\end{array}$ & $\begin{array}{l}\text { Tergantung illatnya. } \\
\text { Bagi yang men- } \\
\text { ganggap ada unsur } \\
\text { tambahan, akan ber- } \\
\text { pendapat dalam asur- } \\
\text { ansi ada praktik riba } \\
\text { walaupun dinamakan } \\
\text { mudharabah (bagi } \\
\text { hasil). } \\
\text { Dan bagi yang men- } \\
\text { ganggap ini adalah } \\
\text { bagi hasil murni, } \\
\text { asuransi seperti ini } \\
\text { sama saja dengan } \\
\text { menabung dengan } \\
\text { skema bagi hasil. }\end{array}$ & $\begin{array}{l}\text { 1. adakah unsur } \\
\text { tambahan atau } \\
\text { penambahan } \\
\text { nilai ?. } \\
\text { 2. adakah unsur } \\
\quad \text { kedzaliman? } \\
\text { Keduanya sangat } \\
\text { menentukan hukum } \\
\text { asuransi. }\end{array}$ \\
\hline
\end{tabular}


Masuk Rp. di PT. Rp.

SD1 1.700.000 Thn ke-2 di PT 3.050.560

SMP 2.550.000 Thn ke-3 di PT 3.433.710

SMA 3.400.000 Thn ke-4 di PT 3.418.013

PT 6.800.000 Thn ke-5 di PT 3.664.110

Bila bapak Ali meninggal dunia dalam masa perjanjian (misalnya pada tahun ke 5):

Ahli warisnya menerima:

Dana kebajikan Rp. 12.000.000,-

- Rekening tabungan Rp.2.625.000,-

Bagi hasil Rp. 975.521

Total Rp. 15.600.521

Penerima hibah memperoleh:

Dana pendidikan sesuai rencana

\section{CONTOH 2}

Kasus lama yang ada nash 2: (Yang dianalogikan dengannya)

\begin{tabular}{|c|c|c|}
\hline JUAL BELI GARAR & HUKUM & ILLAT \\
\hline $\begin{array}{l}\text { Jual beli garar adalah jual } \\
\text { beli yang didasarkan atas } \\
\text { ketidakjelasan sejak dimu- } \\
\text { lainya akad, atau jual beli } \\
\text { yang ketidakjelasannya di } \\
\text { waktu yang akan datang }{ }^{4} \text {. } \\
\text { Misal: } \\
\text { 1. Jual ikan yang masih di } \\
\text { kolam. } \\
\text { 2. menjual buah-buahan } \\
\text { yang masih muda/be- } \\
\text { lum laik dipetik. } \\
\text { 3. Menjual anak hewan } \\
\text { yang masih berada } \\
\text { dalam perut ibunya. }\end{array}$ & $\begin{array}{l}\text { Haram berdasarkan } \\
\text { al-Qur'an dan al-Hadits } \\
\text { (HR. Muslim) }\end{array}$ & 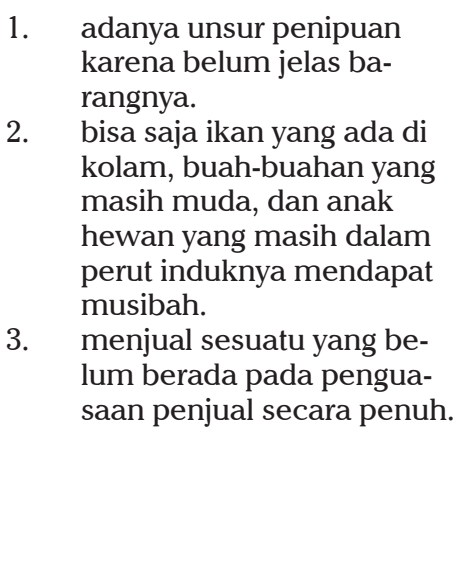 \\
\hline
\end{tabular}

Kasus baru: (Yang dianalogikan dengan kasus jual beli garar)

\begin{tabular}{|l|l|l|}
\hline \multicolumn{1}{|c|}{ ASURANSI } & \multicolumn{1}{|c|}{ HUKUM } & \multicolumn{1}{c|}{ ILLAT } \\
\hline $\begin{array}{l}\text { Asuransi adalah transaksi per- } \\
\text { janjian antara dua pihak; pihak } \\
\begin{array}{l}\text { yang satu berkewajiban memba- } \\
\text { yar iuran dan pihak yang }\end{array}\end{array}$ & $\begin{array}{l}\text { Tergantung 'illatnya. } \\
\text { Bagi kelompok yang meli- } \\
\text { hat adanya unsur peni- } \\
\text { puan, ketidakjelasan }\end{array}$ & $\begin{array}{l}\text { Adakah illat-illat bai' } \\
\text { al-garar di di sini ?. } \\
\text { Adakah unsur peni- } \\
\text { puan? }\end{array}$ \\
\hline
\end{tabular}




\begin{tabular}{|l|l|l|}
\hline $\begin{array}{l}\text { lain berkewajiban memberikan } \\
\text { jaminan sepenuhnya kepada } \\
\text { pembayar iuran jika terjadi } \\
\text { sesuatu yang menimpa pihak } \\
\text { pertama sesuai dengan perjan- } \\
\text { jian yang dibuat"5. }\end{array}$ & $\begin{array}{l}\text { (gharar) dalam asur- } \\
\text { ansi, maka menganggap } \\
\text { hukumnya sama dengan } \\
\text { bai' al-gharar, haram. Se- } \\
\text { mentara bagi kelompok } \\
\text { yang menganggap tidak } \\
\text { ada illat-illat tersebut, } \\
\text { menganggap hukumnya } \\
\text { boleh. }\end{array}$ & \\
\hline
\end{tabular}

\section{CONTOH 3}

Kasus lama yang ada nash 3: (Yang dianalogikan dengannya)

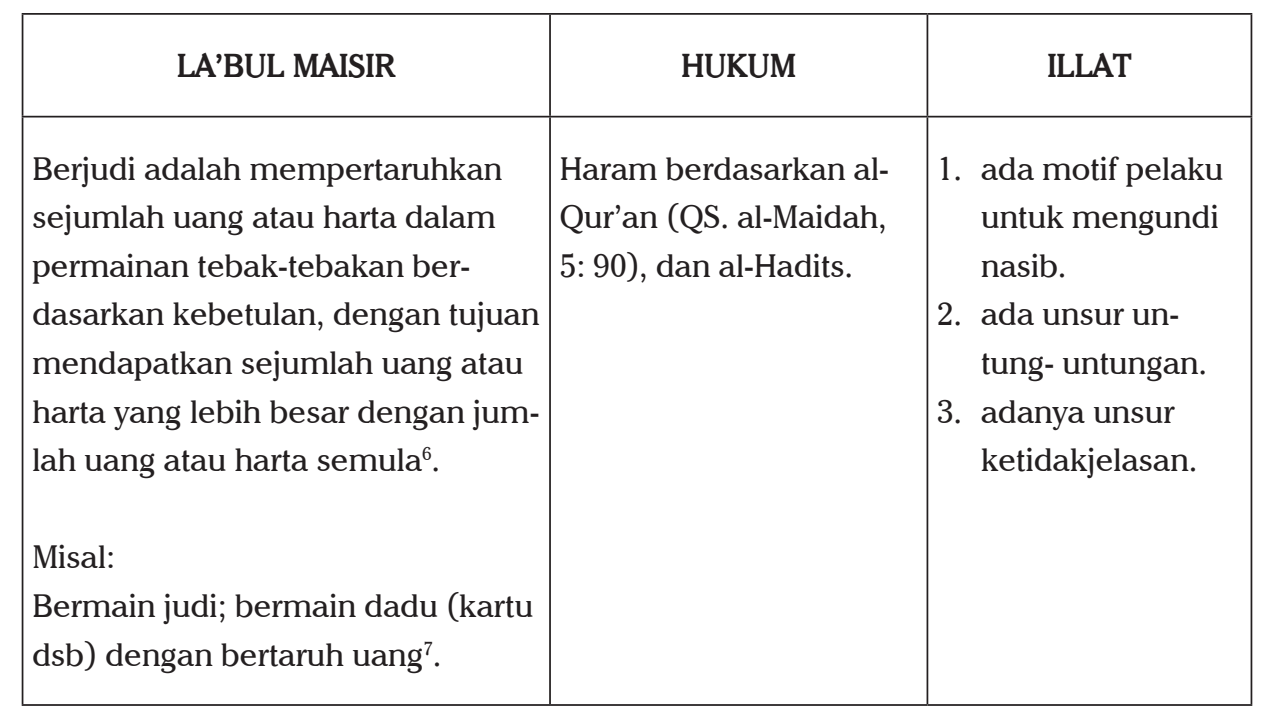

Kasus baru: (Yang dianalogikan dengan kasus la'bul maisir)

\begin{tabular}{|c|c|c|}
\hline ASURANSI & HUKUM & ILLAT \\
\hline $\begin{array}{l}\text { Asuransi adalah transaksi perjanjian } \\
\text { antara dua pihak; pihak yang satu } \\
\text { berkewajiban membayar iuran dan } \\
\text { pihak yang lain berkewajiban mem- } \\
\text { berikan jaminan sepenuhnya kepada } \\
\text { pembayar iuran jika terjadi sesuatu } \\
\text { yang menimpa pihak pertama sesuai } \\
\text { dengan perjanjian yang dibuat". }\end{array}$ & $\begin{array}{l}\text { Tergantung 'illatnya. } \\
\text { Bagi yang mengatakan } \\
\text { adanya illat-illat perjudi- } \\
\text { an pada kasus asuransi, } \\
\text { menganggap asuransi } \\
\text { sama dengan hukum } \\
\text { perjudian, diharamkan. } \\
\text { Sementara bagi yang }\end{array}$ & 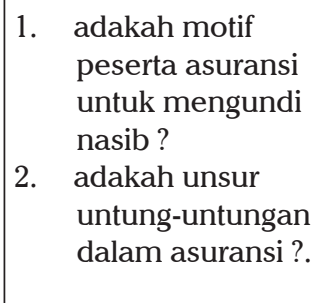 \\
\hline
\end{tabular}




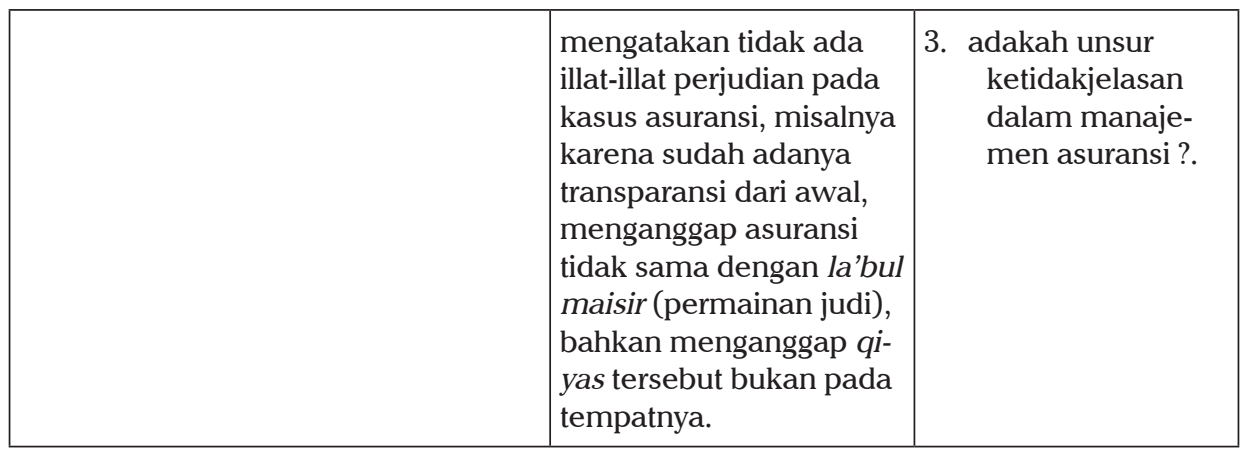

\section{Penutup}

Dari uraian yang telah dikemukakan di atas, jelaslah bahwa masalah asuransi adalah masalah ijtihâdiyyah dan sekaligus khilâfiyyah yang terjadi di kalangan pakar hukum Islam kontemporer. Artinya, suatu masalah yang belum mempunyai ketetapan hukum secara mutlak. Dua kelompok yang mempunyai pendapat yang berbeda - boleh dan tidak boleh - pada dasarnya sepakat menyatakan bahwa riba, maysir, dan bay' gararitu adalah sesuatu yang diharamkan karena adanya kezaliman, unsur perjudian dan penipuan di dalamnya, dan inilah 'illat mengapa praktik muamalah seperti itu dilarang, namun kemudian mereka berbeda pendapat dalam merefleksikan 'illat tersebut dalam kasus asuransi modern.

Menurut penulis, sebab perbedaan pendapat bukan pada metode penetapan hukumnya, karena keduanya sama-sama menggunakan metode qiyâs, akan tetapi sebab perbedaan lebih pada materi-materi qiyâs itu sendiri dan cara menginterpretasikan 'illat-nya, yaitu ashl (yang dianalogikan dengannya), di mana satu pihak memandang adanya kesamaan 'illat antara ashl atau kasus yang sudah status hukumnya secara jelas (dalam hal ini praktik riba, maysir, dan bay' al-garar) dengan far' (dalam hal ini asuransi). Sementara pihak lain memandang sebaliknya, 'illat pengharaman riba, maysir, dan bay' al-garar tidak terdapat pada praktik asuransi.

Oleh karena itu, mengetahui ada tidaknya 'illat dalam praktik asuransi modern dibutuhkan perlu adanya analisis oleh kolaborasi keahlian antara ahli asuransi dengan ahli hukum Islam, artinya perlu melibatkan praktisi asuransi itu sendiri dalam menetapkan hukum asuransi. Dimana dalam hal transparansi dan segala sesuatu yang terkait dengan managemen 
asuransi, biarlah ahli asuransi yang berbicara. Setelah itu biarkanlah para ahli hukum Islam menentukan sikap dan status hukumnya.

\section{Pustaka Acuan}

Abduh, Isâ, Al-Ta'mîn Bayna al-Hill wa al-Tahrîm, Qâhirah: Dâr al-I'tishâm, t.th. Abdul Manan, Muhammad, Teori dan Praktik Ekonomi Islam, editor, H.M. Sonhadji, dkk, Yogyakarta: PT. Dana Bakti Prima Yasa, 1997.

Abu Zahrah, Muhammad, Ushûl Fiqh, Dâr al-Fikr al-Arabi, 1377 H./1958 M., Ali, Hasan, Asuransi dalam perpektif Hukum Islam, Cet. ke-5 Jakarta: Prenada Media, 2005.

Asuransi Takaful, Brosur dikeluarkan oleh PT. Asuransi Takaful Keluarga, Jl. Mampang Prapatan Ray No.100, Jakarta.

Bukhari, al-, Imâm, Shahîh al-Bukhâri, Cet. ke-1, Riyâdl: Dâr al-Salam Li alNasyri wa al- Tawzi', 1417 H - 1997 M.

Dahlan, Abdul Aziz, dkk editor, Ensiklopedi Hukum Islam, Jakarta: Ichtiar Baru van Hoeve, 1996.

Dasûqi, al-, Muhammad Sayyid, Al-Ta'mîn wa Mawqif al-Syarîah alIslâmiyah Minhu, Kairo: Majlis al-A'la li al-Syu'un al-Islâmiyah, 1968.

Departemen Pendidikan dan Kebudayaan, Kamus Besar Bahasa Indonesia, Jakarta: Balai Pustaka, 1990.

Fathurrahman Djamil, Filsafat Hukum Islam, cet.ke-III, Pamulang: Logos Wacana Ilmu, 1999.

Husayn, Hamid Hasan, Hukm al-Syarî'ah al-Islâmiyah fi 'Uqûd al-Ta'mîn, terj. Aisyul Muzakki Ishak, Jakarta: Pustaka Firdaus, 1996.

Imârah, Muhammad, Qâmûs al-Mushthalahât al-Iqtishâdiyah fi al-Hadlârah al-Islâmiyah, Beirut: Dâr al-Syurûq, 1993.

Isâ, Abd al-Rahmân, al-Mu'âmalat al-Hadîtsah wa Ahkâmuhâ, Mesir: alMukhaimir, t.th.

John M. Echols dan Hassan Sadilly, Kamus Inggris-Indonesia, Jakarta: Gramedia, 1990

Jurjâni, al-, Kitâb At-Ta'rifat, Beirut, Lubnân: Dâr al-Kutub al-'Ilmiyyah 1408 $\mathrm{H}-1988 \mathrm{M}$.

Khafifi, al-, Syaikh Ali, al-Ta'mîn wa Hukmuhâ 'alâ Hudâ al-Syarîah alIslâmiyah, Makkah, 1968. 
Khallâf, al-, Abd al-Wahhâb, 'Ilmu Ushûl al-Fiqh, Kuwait: Dâr al-Qalam, 1978.

Mushthafa, Ibrahim, dkk, Al-Mu'jam Al-Wasith, Turki, Istambul: al-Maktabah al-Islâmiyah, t.th.

Muslim, al-, Imâm, Shahîh Muslim, Cet. 1, Vol. 4, Beirut: Dâr Ibnu Hazam, $1416 \mathrm{H}-1995 \mathrm{M}$.

Musthafâ Ahmad al-Zarqâ', 'Aqd al-Ta'mîn wa Mawqif al-Syarî'ah alIslâmiyah Minhu, Makkah, 1968.

Prodjodikoro, Wirjono, Hukum Asuransi di Indonesia, Jakarta: Pembimbing, 1958.

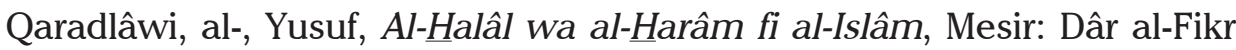
al-Arabi, 1984.

Rahman, Afzalur, Doktrin Ekonomi Islam, terj. Soeroyo dan Nastangin,, Vol. ke-4, Yogyakarta: PT. Dana Bakti Wakaf, 1996

Sâbiq, al-Sayyid, Fiqh al-Sunnah, Vol.ke-3, Beirut: Dâr al-Kutub al-Ilmiyah, 1998.

Salim, A. Abbas, Dasar-dasar Asuransi Principles of Insurance, cet. ke-1, Jakarta: PT. Rajagrapindo Persada, 1995.

Sumitro, Warkum, Asas-asas Perbankan Islam dan Lembaga-lembaga Terkait, cet. ke-4 Jakarta: Rajawali Press, 2004.

Suyûthi, al-, Jalâl al-Dîn, Al-Asybâh wa al-Nazhâir, Singapore: Sulaiman Mar'ie, t.t..

Syafe'i, Rachmat, Ilmu Ushul Fiqh untuk IAIN, STAIN, PTAIS, Bandung: Pustaka Setia, 1999

Syâthibi, al-, Abu Ishâq, Al-Muwâfaqât fi Ushûl al-Syarî’ah, vol. ke-1, cet.ke4, Beirut: Dâr al-Ma'ârifah, 1999.

Zuhayli, Wahbah, Al-Fiqh al-Islâmi wa Adillatuh, Dimasyqi: Dâr al-Fikri, $1417 \mathrm{H} / 1996 \mathrm{M}$.

Zuhdi, Masjfuk, Masail Fiqhiyah, Jakarta: Haji Masagung, 1994

Zuhri, Muh, Riba dalam Al-Qur'an dan Masalah Perbankan Sebuah Tilikan Antisipatif, cet. ke-2, Jakarta: Raja Grafindo Persada, 1997 